Nat. Hazards Earth Syst. Sci. Discuss., doi:10.5194/nhess-2016-83, 2016

Manuscript under review for journal Nat. Hazards Earth Syst. Sci.

Published: 18 March 2016

(c) Author(s) 2016. CC-BY 3.0 License.

\title{
1 Sensitivity study of the tropical Pacific precipitation
} 2 anomalies

\author{
3 Shouwen Zhang ${ }^{1}$, Hua Jiang ${ }^{1}$, Hui Wang ${ }^{1,2}$, Ling Du ${ }^{3}$, Dakui Wang ${ }^{1}$ \\ $4 \quad{ }^{1}$ National Marine Environment Forecasting Center, State Oceanic Administration, Beijing 100081, China \\ $5{ }^{2}$ Key Laboratory of Research on Marine Hazards Forecasting, National Marine Environmental Forecasting \\ 6 Center, Beijing 100081, China \\ $7{ }^{3}$ Department of Oceanography, Ocean University of China, Qingdao 266100, China \\ Correspondence to: Hua Jiang (hjiang@nmefc.gov.cn)
}

Abstract. Climate model results have shown that precipitation in the tropical Pacific Ocean will change up to $15 \%$ and $25 \%$ in one century. In this paper, both reanalysis data and climate model are used to study the response of global ocean and atmosphere to precipitation anomalies in the tropical Pacific Ocean. It shows that positive precipitation anomalies could trigger an El Nino-like SSTA response, with warmer SST in the east tropical Pacific Ocean and slightly cooler SST in the west tropical Pacific Ocean. The zonal tropical ocean currents change significantly, of which the magnitudes and directions are mainly relying on the intensity of the precipitation anomalies. Through a wave train encompassing the whole Northern Hemisphere named as the Circumglobal Waveguide Pattern (CWP), the North Atlantic atmospheric circulation responds to the freshwater anomalies in a NAO-like pattern. The anomalous atmospheric circulation transport sea ice to the North Atlantic Ocean. The sea ice melts in summer and freshen the upper ocean, which makes the ocean more stable. It thus constrains vertical heat transport and makes the upper water cooler, forming a significant positive feedback mechanism.

Key words: precipitation; tropical Pacific Ocean; sensitivity; anomalies

\section{Introduction}

Air-sea freshwater flux, defined as precipitation $(\mathrm{P})$ minus evaporation $(\mathrm{E}),(\mathrm{PmE})$, is an important indicator representing the water exchange between atmospheric and ocean. Previous studies have found that mean PmE would increase under global warming mainly through the increasing saturation level of moisture, and $16 \%$ to $24 \%$ intensification of the global water cycle will occur in a future $2^{\circ}$ to $3^{\circ}$ warmer world (Durack et al. 2012). Especially, the precipitation will experience significant changes in frequency and spatial distribution in the future. Therefore, freshwater changes in response to climate change pose a more severe risk to human societies and ecosystems than warming alone.

Prior studies mainly focus on the response of Atlantic thermohaline circulation to freshwater anomalies in the North Atlantic high latitudes region, which usually take the water-hosing experiments as typical research method and have reached qualitative conclusions (Broecker et al., 2003; Curry et al., 2003; Timmermann et al., 2005; Wu et al., 2008). It has also been found that freshwater forcing plays an active role in maintain the Pacific climate, especially the ENSO phenomenon (Huang and Mehta, 2005; Zhang et al., 2009; Zheng et al., 2012). In addition, oceanic and atmospheric responses to local freshwater forcing have been paid substantial attention (Williams et al., 2006; Stouffer et al., 2007; Zhang et al., 2011a, 
Nat. Hazards Earth Syst. Sci. Discuss., doi:10.5194/nhess-2016-83, 2016

Manuscript under review for journal Nat. Hazards Earth Syst. Sci.

Published: 18 March 2016

(c) Author(s) 2016. CC-BY 3.0 License.

Natural Hazards

and Earth System

Sciences

Discussions

2011b).

2 The moisture saturation will increase in a future persistent global warming world, resulting in significant

3 change of freshwater flux. Compared to evaporation, precipitation plays a more important role in the

4 freshwater change. The precipitation in the tropical Pacific Ocean will increase substantially over the

5 coming one hundred years (Laine et al., 2014). To quantitate the change, we analyzed the precipitation

6 variations following Laine et al., (2014) in Representative Concentration Pathway (RCP) 4.5 and 8.5

7 scenarios. Results have shown that the precipitation will change most significantly in the tropical Pacific

8 Ocean, exceeding $15 \%$ and $25 \%$ than their climatology in RCP 4.5 and 8.5 scenarios respectively in one

9 century. Meanwhile, the change of evaporation is comparatively weak, with an increase less than 5\%. At present, there are sufficient useful tools to research the effect of freshwater on the climate change owing to the availability of the reliable oceanic and atmospheric datasets and the development of the global climate models.

In this paper, historical oceanic and atmospheric datasets are used to evaluate the characteristics of ocean currents and sea surface temperature (SST) during the strong precipitation periods using composite analysis method. Then, experiment performed by the CESM model is used to study the response of global ocean and atmosphere to a $10 \%$ increase of precipitation in the tropical Pacific Ocean. The arrangement of the article is as follows, section 1 describes the research background and contents. Section 2 describes the data and model used in this study. Section 3 analyzes the response of ocean currents and SST in the extreme tropical Pacific Ocean precipitation context. The results of model simulation are shown in section 4. Finally, these results are summarized and discussed in section 5.

\section{Data and model}

The Global Precipitation Climatology Project (GPCP) dataset (Huffman et al., 1997; Adler et al., 2003) is used as the source of precipitation data. To analyze the characteristics of tropical currents during extreme tropical precipitation period, three datasets with the same period from 1980 to 2008 are used, which are the European Centre for Medium-Range Weather Forecasts (ECMWF) Reanalysis datasets (ORA-S3, Balmaseda et al., 2008), Global Ocean Data Assimilation System (GODAS, Behringer et al., 2004) and Simple Ocean Data Assimilation (SODA) datasets. It's noteworthy that SST is also extracted from SODA datasets.

Tropical Pacific Ocean $\left(5^{\circ} \mathrm{S}-5^{\circ} \mathrm{N}, 120^{\circ} \mathrm{E}-80^{\circ} \mathrm{W}\right)$ mean precipitation is calculated first, and then 20 months corresponding to the largest and smallest precipitation are obtained respectively. A composite analysis method is carried out to examine the differences of SST and currents between strong and weak precipitation over the tropical Pacific Ocean. In each of the analyses, a test of statistical significance based on t-test, is performed to identify geographical regions where the composite results at the $95 \%$ confidence level.

We use the Community Earth System Model (CESM) version 1, a fully coupled, global climate model maintained by the Climate and Global Dynamics Division (CGD) at the National Center for Atmospheric Research (NCAR). CESM consists of five geophysical models: the atmosphere model is Community Atmosphere Model (CAM5), the ocean model is based on the Parallel Ocean Program version 2 developed by the Los Alamos National Laboratory (POP2), the sea ice model is Community Ice Code (CICE4), the land model is Community Land Model (CLM4) and the land ice model is Community Ice Sheet Model (CISM). A coupler (CPL7) is used to coordinate the models and passe information among them. The CESM used in this paper has an atmosphere resolution of 1.9 (zonal)*2.5(meridional)*40, the 
Nat. Hazards Earth Syst. Sci. Discuss., doi:10.5194/nhess-2016-83, 2016

Manuscript under review for journal Nat. Hazards Earth Syst. Sci.

Published: 18 March 2016

(c) Author(s) 2016. CC-BY 3.0 License.

2 2012). The sea ice model uses the same horizontal grid as that of the ocean model, while grids of the land

3 model and the atmosphere model are identical. Good performance in simulating the freshwater forcing and

4 climate change have been shown by CESM in many studies (Kirtman et al., 2011; Yeager et al., 2012;

5 Danabasoglu et al., 2012).

6 A control experiment integrated for 150 years is carried out focusing on the ocean surface and atmosphere

7 adjustment. Based on the precipitation projection in one century that the tropical Pacific precipitation will

8 change $15 \% \sim 25 \%$, we are conservative to add $10 \%$ of precipitation on each time-step in the coupler,

9 which has the same pattern of the most robust precipitation in the tropical Pacific Ocean $\left(5^{\circ} \mathrm{S}-5^{\circ} \mathrm{N}\right.$,

$\left.10120^{\circ} \mathrm{E}-80^{\circ} \mathrm{W}\right)$. The sensitivity experiment begins at the end of 60 years of the control experiment, and then

11 integrates forward for another 90 years. The difference between the sensitive experiment and the control

\section{Observation results}

Precipitation correlates significantly with SST over the tropical Pacific Ocean. As shown in Fig.1, SST rises more than $6^{\circ} \mathrm{C}$ in the tropical eastern Pacific Ocean on account of the positive precipitation anomalies of the whole tropical Pacific Ocean. It is accompanied by weak decreasing in the tropical western Pacific Ocean, which forms an obvious temperature gradient over the tropical Pacific Ocean. The spatial distribution of temperature anomalies caused by strong precipitation resembles with the SST anomalies characteristics during El Nino periods.

In addition, equatorial currents also demonstrate significant changing. We use three different kinds of current datasets to increase the credibility of the results, as the accuracy of ocean current datasets is much lower than that of SST. It is shown that, three ocean current datasets have good manifestation in terms of both location and magnitude. It's noteworthy that the north branch of the south equatorial current at $180^{\circ}$ in SODA datasets is much deeper than that in the other two datasets. Specifically, the south and north equatorial currents show positive anomalies, especially for the north part of the south equatorial current, which indicate strong weakening of the currents. For both profiles, the equatorial counter current shows strong negative anomalies. The change is most significant as the anomaly is even larger than its climatology. It's mainly because the equatorial counter current locates at the equatorial calm zone and rainfall in this region is abundant. Changes of equatorial latent current of two profiles are slightly different. Negative anomalies are robust in the middle and upper part of the $180^{\circ}$ profile, while it is in the middle and lower part of the $220^{\circ}$ profile. The range of significant weakening could be up to half of its climatology. 
Nat. Hazards Earth Syst. Sci. Discuss., doi:10.5194/nhess-2016-83, 2016

Manuscript under review for journal Nat. Hazards Earth Syst. Sci.

Published: 18 March 2016

(c) Author(s) 2016. CC-BY 3.0 License.

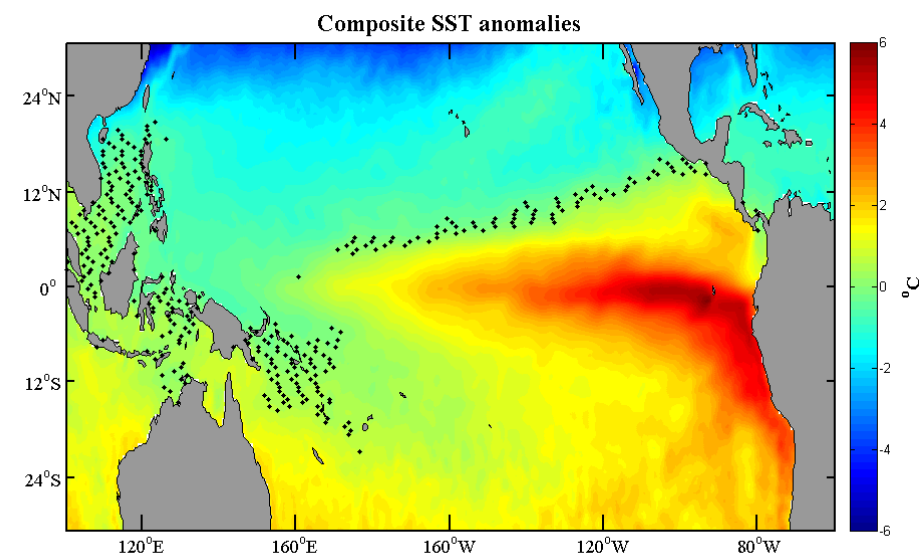

Figure 1: Composite map of SST anomalies difference between strong and weak precipitation periods over the tropical Pacific. Dotted regions are not at $95 \%$ confidence level. Units: ${ }^{\circ} \mathrm{C}$
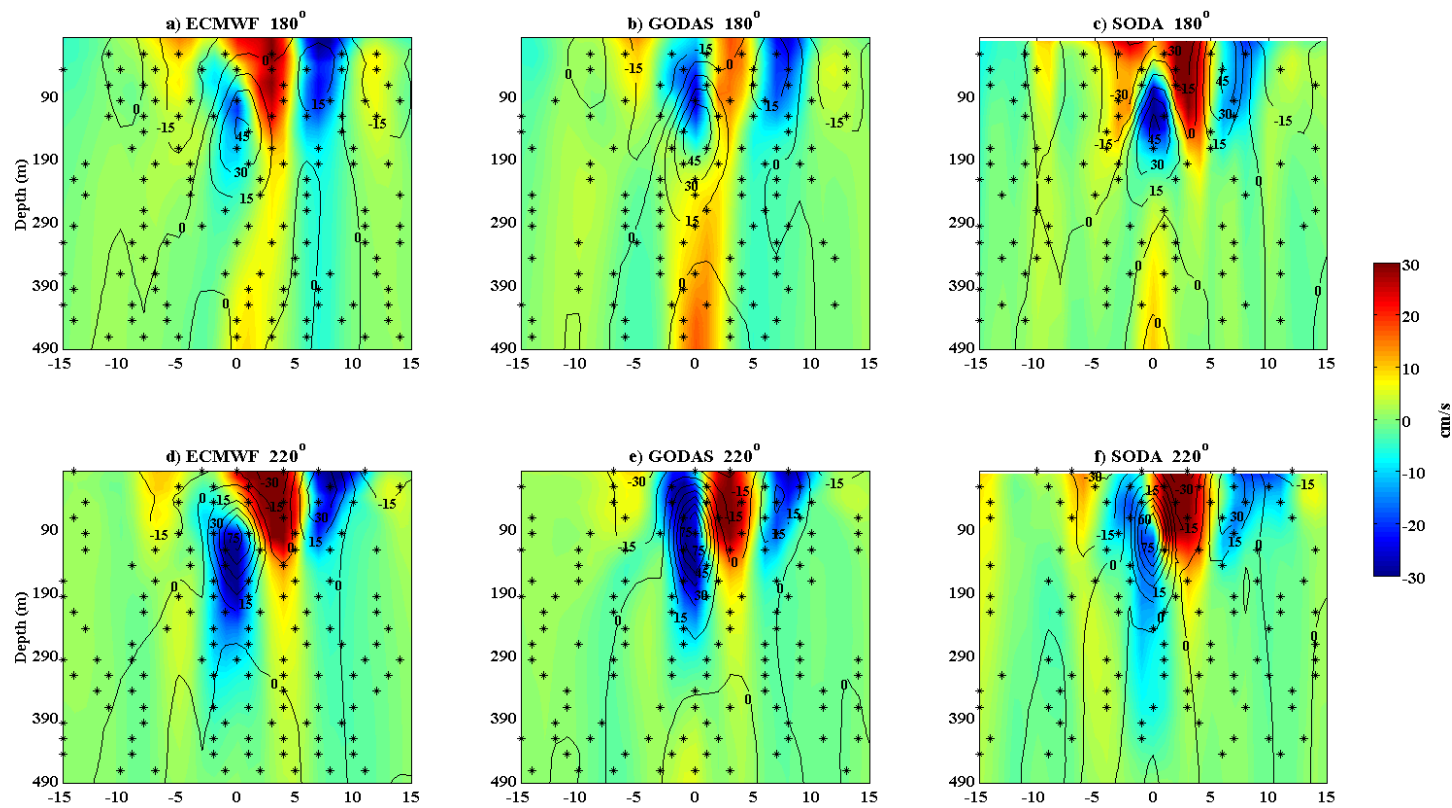

\section{$7 \quad 4$ Model results}

8 Under the extra 10\% precipitation forcing in the tropical Pacific Ocean, SST shows significant decreasing

9 pattern over the Northern Hemisphere, especially over the northwest Pacific Ocean and the Northern 
Nat. Hazards Earth Syst. Sci. Discuss., doi:10.5194/nhess-2016-83, 2016

Manuscript under review for journal Nat. Hazards Earth Syst. Sci.

Published: 18 March 2016

(c) Author(s) 2016. CC-BY 3.0 License. second mode accounting for $17 \%$ of the total variance is characterized by an El Nino-like pattern that the spatial distribution of SST anomalies is opposite in the western and eastern Pacific Ocean. Power spectrum method is used to capture the main features of the second principle component. The power spectrum peaks at 5 and 3.2 years, showing significant interannual variability. It is noted that the spatial distribution of the second mode is similar with the composite maps of SST anomalies in Fig.1, confirming the El Nino-like response of SST anomalies.

Four profiles are select to analyze the response of tropical ocean currents to the extra $10 \%$ precipitation forcing. Profiles along $180^{\circ}$ and $220^{\circ}$ are used to represent the Pacific Ocean, and the $60^{\circ}$ and $330^{\circ}$ profiles represent the Indian Ocean and the Atlantic Ocean respectively. Compared with the observation results, main features of the tropical Pacific Ocean currents are well simulated by CESM (Fig.4a/b and Fig.2). Previous studies have shown that the most significant changes of currents occur in the Pacific Ocean. For the $180^{\circ}$ profile, the South Equatorial Current weakens up to $8 \mathrm{~cm} / \mathrm{s}$. The Equatorial Counter Current shows negative anomalies on its north flank and significant positives anomalies on the upper part of the Equatorial Latent Current, which results in the upward-tilting thermocline. For the $220^{\circ}$ profile, the South Equatorial Current and the upper part of the Equatorial Latent Current weaken, and the lower part of the Equatorial Latent Current strengthen, which results in the thermocline deepening. Based on in-situ measurements, it has been found that precipitation over the tropical Pacific Ocean east of $160^{\circ}$ increases during the 1997-1998 El Nino, while the ascending branch of the Walker circulation migrates eastward and the Intertropical Convergence Zone (ITCZ) and South Pacific Convergence Zone (SPCZ) migrate equatorward (Delcroix et al., (2002)). These changes are also accompanied by anomalous energetic eastward surface currents along the equator, which is consistent with the results in this paper. Comparatively speaking, currents in the Indian Ocean show little changes, and south subtropical ocean is the area of most remarkable changes. However, the most remarkable changes of the Atlantic Ocean locate in high latitudes (not shown), where the Gulf Stream weakens while the West Wind Drift strengthens.
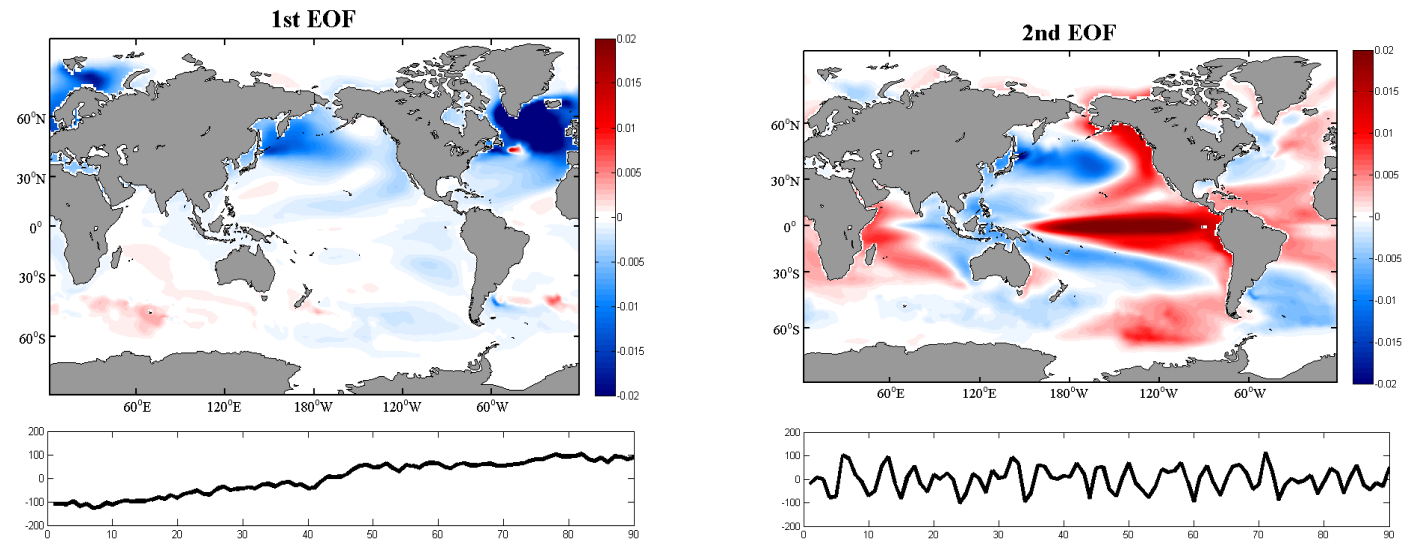

Figure 3: Spatial and temporal distribution of the first two modes of SST anomalies between the sensitivity experiment and the control experiment

The model largely reproduces the currents characteristics shown in Section.3, especially for the $180^{\circ}$ profile, where the South Pacific Current and the upper part of the Equatorial Latent Current weaken significantly. However, the positive anomalies lie between $150-300 \mathrm{~m}$ depth reflecting the strengthening of 
Nat. Hazards Earth Syst. Sci. Discuss., doi:10.5194/nhess-2016-83, 2016

Manuscript under review for journal Nat. Hazards Earth Syst. Sci.

Published: 18 March 2016

(c) Author(s) 2016. CC-BY 3.0 License.

the Equatorial Latent Current is quite different from the composite results shown in Fig.2. For the $220^{\circ}$

profile, the equatorial counter current is not obvious. The differences between the model results and the composite results are mainly due to the intensity of precipitation. The composite analysis is conducted for the extreme precipitation conditions while the model simulates the response to the $10 \%$ precipitation intensification. It reveals that precipitation in the tropical Pacific Ocean can not only influence the magnitude of zonal currents, but also its direction especially over the east Pacific Ocean.
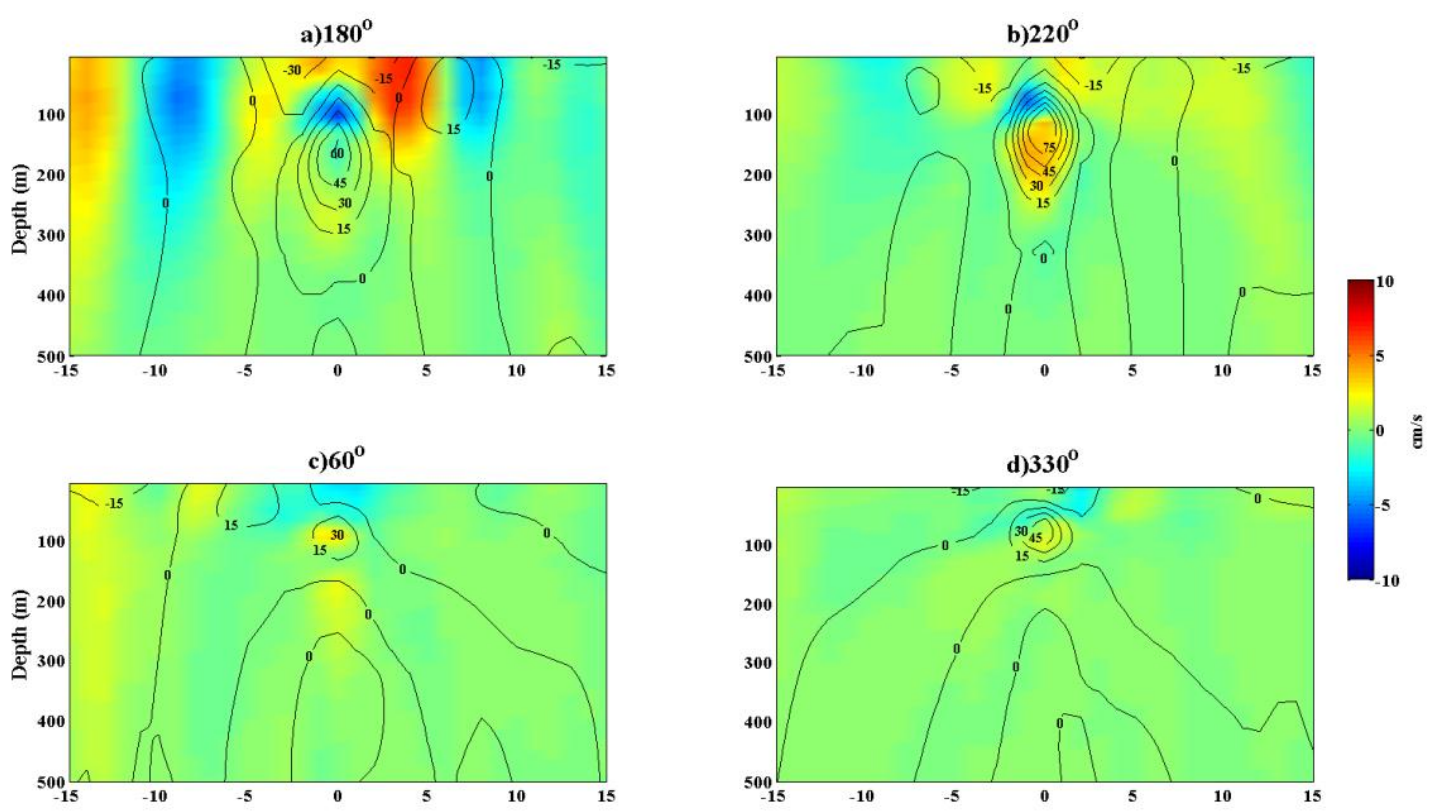

Figure 4: Climatology and anomalies of ocean zonal current on four different profiles $\left(\mathrm{a}: 180^{\circ} ; \mathbf{b}^{\circ}: \mathbf{2 2 0}^{\circ} ; \mathbf{c : ~}^{\circ} 0^{\circ}\right.$; $\mathrm{d}: 330^{\circ}$. Contours represent the vertical climatology distribution of zonal current of the control experiment, while the shading area represents the current anomalies. Unit:cm/s)

Strong precipitation anomaly in the tropical Pacific Ocean could also cause significant change remotely. The atmospheric circulation anomaly in equilibrium state is most significant around the Greenland Island and well correlates with the sea surface temperature anomaly (SSTA) in Nino3 region. 500hpa geopotential height anomalies are compared with the NINO3 SSTA, their annual correlation coefficient is 0.32 while it's 0.4 with a 7 years low-pass filtering. It shows that the El Nino-like SSTA could stimulate atmospheric circulation anomaly in the North Atlantic high latitudes region, reflecting a fast process connecting the tropical Pacific Ocean and the sub-Arctic region (Jevrejeva et al., 2004). It has been confirmed that changes in tropical heating could trigger remote atmospheric response over the North Atlantic Ocean, which changes the SST and sea ice in this region (Hoerling et al., 2001). Selten et al., (2004) studies the relationship between intensified tropical precipitation and the North Atlantic Oscillation (NAO) trend under the circumstance of global warming. They found that intensified precipitation could change the extra-tropical circulation in winter, which is characterized by a wave train encompassing the whole Northern Hemisphere. The concept of this wave train, which is named as Circumglobal Waveguide Pattern (CWP), is first brought forward by Branstator et al., (2002). 
Nat. Hazards Earth Syst. Sci. Discuss., doi:10.5194/nhess-2016-83, 2016

Manuscript under review for journal Nat. Hazards Earth Syst. Sci.

Published: 18 March 2016

(c) Author(s) 2016. CC-BY 3.0 License.

a) 100hpa

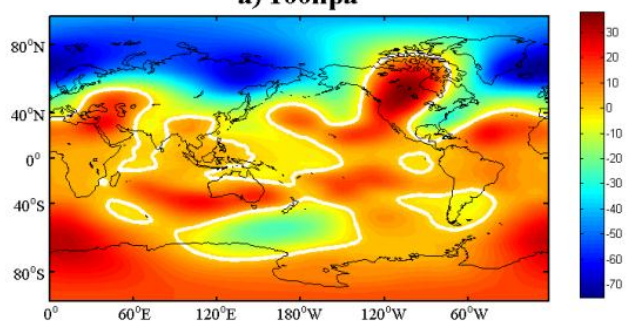

c) $500 \mathrm{hpa}$

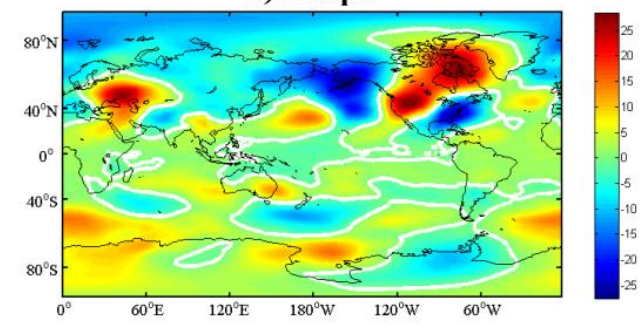

b) 300hpa

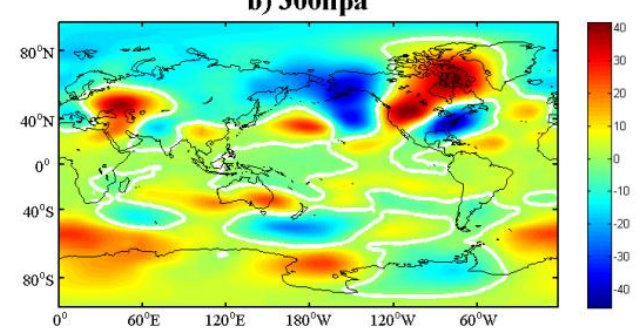

d) $900 \mathrm{hpa}$

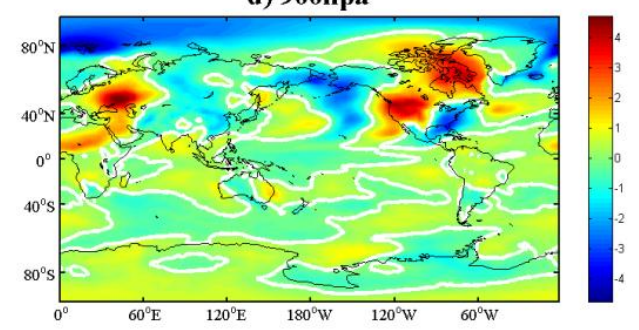

Figure 5: Geopotential height anomalies in boreal winter averaged over the first ten years. a):100hpa;b):300hpa;c):500hpa and d) 900hpa. (White lines are contours for zero, Units: m)

The geopotential height anomalies in winter averaged over the first ten years of the simulation are used to analyze the response of atmosphere circulation to precipitation anomaly in the tropical Pacific Ocean. It shows that the anomalies strengthen from lower atmosphere to upper atmosphere, which is characterized by a barotropic distribution (Fig.5). Spatial distribution of the 300hpa geopotential height anomalies shows a CWP pattern, which resembles the wave-train pattern in Selten et al., (2004). Branstator et al., (2002) indicate that the tropical ocean between $150^{\circ} \mathrm{E}$ and $180^{\circ} \mathrm{E}$ is easier to drive the CWP, which coincide the location with the water-hosing region in their sensitive experiment.

The negative and positive atmosphere anomalies are in the east part of the Greenland Island and in the Atlantic subtropical high region respectively, which resembles the positive phase of NAO. To further study the result of atmospheric circulation anomaly, sea ice extent and ocean-ice freshwater are examined. The sea ice extent in the Arctic Ocean exhibits clear seasonality with the maximum and minimum occurring in the boreal winter and boreal summer respectively. In summer, the sea ice extent exceeds $60 \%$, which mainly locates around the North Pole, close to the Greenland Island and the Canadian Archipelago. In winter, the whole Arctic Ocean except the west part of the Europe is covered by thick sea ice. As for the response in the sensitive experiment, sea ice extent decreases up to $10 \%$ in summer due to the increasing SST in the Pacific Arctic. In the meantime, sea ice extent increases north of the Western Siberia and on both sides of the Greenland Island. The regions with most significant sea ice increasing locate in the Barents Sea and the south part of the Greenland Island (Fig.6). The variable named 'fresh' in Fig.7 represents the freshwater entering into the ocean melted from the sea ice. In summer, fresh changes are mainly along the sea ice, especially north of the Western Siberia and seas surrounding the Greenland Island. The changes are significant on the south part of the Greenland Island in winter. The freshwater along the sea ice edge in summer are accumulated from the Barents Sea. Under the advection effect of the 
Nat. Hazards Earth Syst. Sci. Discuss., doi:10.5194/nhess-2016-83, 2016

Manuscript under review for journal Nat. Hazards Earth Syst. Sci.

Published: 18 March 2016

(c) Author(s) 2016. CC-BY 3.0 License.
Natural Hazards

and Earth System

Sciences

Discussions

(c) (i)
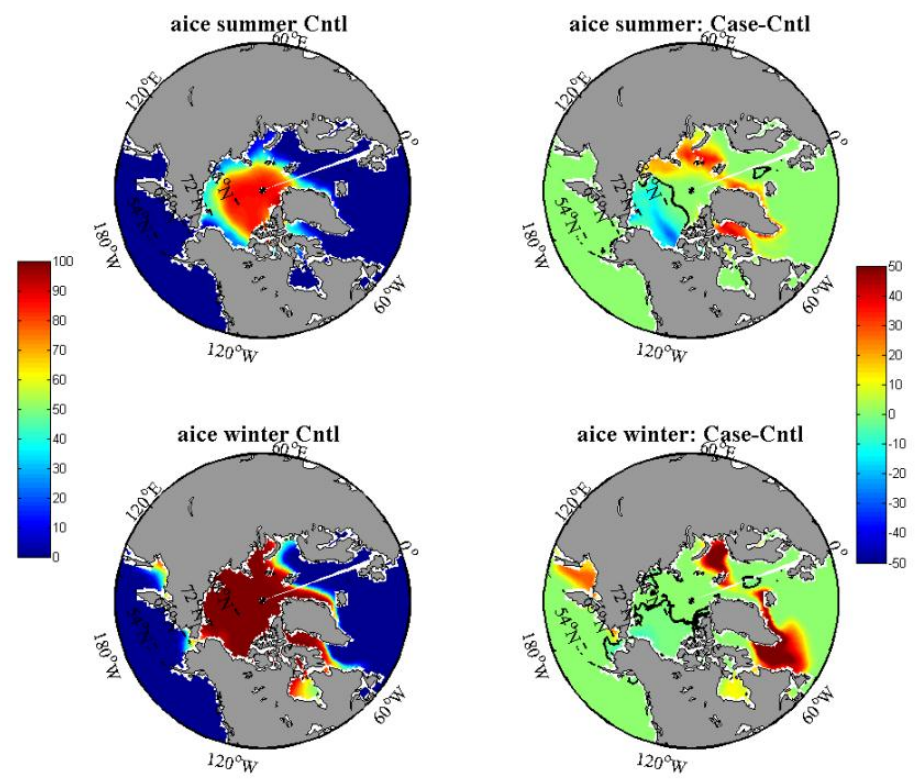

1

Figure 6: Seasonal climatology and anomalies of sea ice extent (Units:\%)
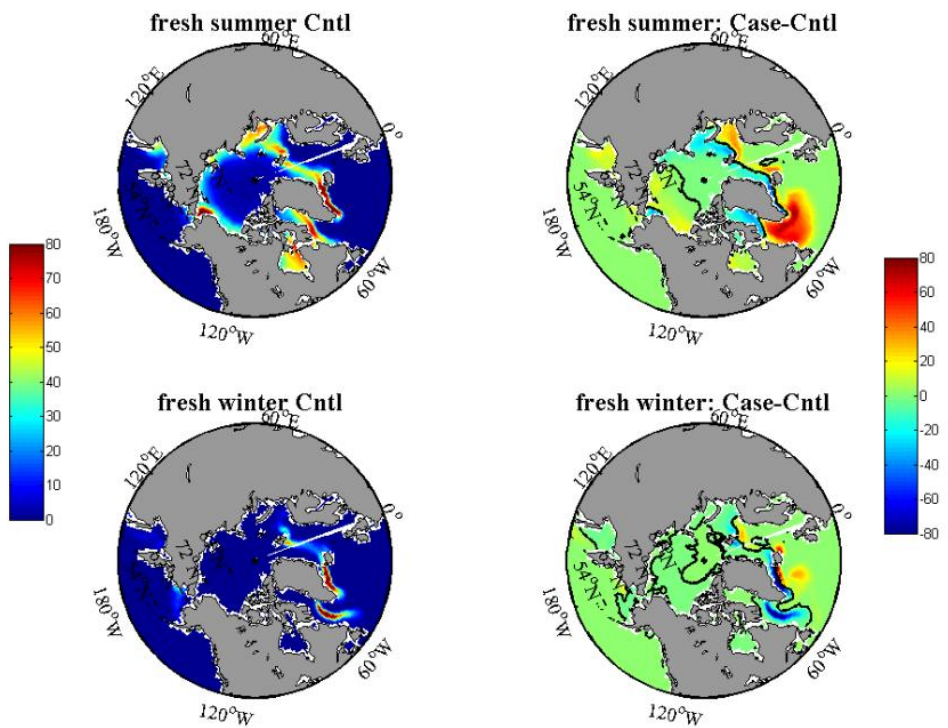

3

5 Transpolar Drift, it enters the north part of the Atlantic Ocean following the East Greenland flow and

6 makes the water in that region cool and fresh. Furthermore, a large amount of sea ice could be transported

Figure 7: Seasonal climatology and anomalies of sea ice extent (Units: cm/day) 
Nat. Hazards Earth Syst. Sci. Discuss., doi:10.5194/nhess-2016-83, 2016

Manuscript under review for journal Nat. Hazards Earth Syst. Sci.

Published: 18 March 2016

(c) Author(s) 2016. CC-BY 3.0 License.

Natural Hazards

and Earth System

Sciences

Discussions

(c) (i)

to the south part of the Greenland Island by the East Greenland flow. The sea water thus gets cooler and fresher when the sea ice is melted. The freshwater in the high latitudes of the North Atlantic Ocean could reduce the mix layer depth and strengthen stratification by lightening the seawater and intensifying the buoyancy flux of the upper ocean. In turn, the strengthened stratification weakens the mixing and entrainment effect, which constrains the vertical heat exchange resulting in the temperature decrease. These processes form a significant positive feedback mechanism.

\section{Summary}

In this study, historical datasets are used to evaluate the characteristics of ocean currents and SST during the strong precipitation periods using composite analysis method. It is found that both the ocean current and SST encounter significant changes during the strong precipitation period. Strong precipitation over the tropical Pacific Ocean could trigger an El Nino-like SSTA response, with the positive SSTA anomalies in the east tropical Pacific Ocean and negative SSTA anomalies in the west tropical Pacific Ocean. Moreover, the tropical Pacific currents in the three different datasets of this study show a consistent response to freshwater anomalies on the tropical Pacific Ocean.

A series of experiments using CESM is performed to study the response of Pacific Ocean to an extra 10\% precipitation forcing. The model results show that the intensified freshwater in the tropical Pacific Ocean could generate a significant cooling tendency in the northwest Pacific Ocean and the Northern Atlantic Ocean, and trigger an El Nino-like warming in the tropical Pacific Ocean. For the $180^{\circ}$ profile, currents change similarly between the model and composite results. However, for the the $220^{\circ}$ profile, it is opposite to the lower part of the Equatorial Latent Current. It reveals that precipitation in the tropical Pacific Ocean can not only influence the magnitude of zonal currents, but also its direction especially over the east Pacific Ocean. Through a wave train encompassing the whole Northern Hemisphere named as CWP, the North Atlantic atmospheric circulation responds to the freshwater anomalies in a NAO-like pattern.. The anomalous atmospheric circulation could transport more freshwater (water and sea ice) from the ice edge to the North Atlantic Ocean. The sea ice melts in summer and freshen the upper ocean, which makes the ocean more stable. It thus constrains vertical heat transport and makes the upper water cooler, forming a significant positive feedback mechanism.

\section{Data availability}

Reanalysis datasets used in this study (GPCP, ECMWF, GODAS and SODA) are all obtained from ASIA-PACIFIC DATA-RESEARCH CENTER (apdrc), with the website address http://apdrc.soest.hawaii. $\underline{\text { edu/las/ v6/dataset?catitem }=0}$

\section{Acknowledgement}

This study is supported by the Public science and technology research funds projects of ocean (201505013), NSFC project Nos. 41376008, 41376016, 41576029 and 41106024. 
Nat. Hazards Earth Syst. Sci. Discuss., doi:10.5194/nhess-2016-83, 2016

Manuscript under review for journal Nat. Hazards Earth Syst. Sci.

Published: 18 March 2016

(c) Author(s) 2016. CC-BY 3.0 License.

\section{Reference}

Adler, R. F., et al.: The Version 2 Global Precipitation Climatology Project (GPCP) Monthly Precipitation Analysis (1979-Present), J. Hydrometeorol., 4, 1147 - 1167, doi: 10.1175/1525-7541(2003)004<1147: TVGPCP>2.0.CO; 2, 2003.

Balmaseda, M. A., Vidard, A., and Anderson, D. L. T.: The ECMWF ocean analysis system ORA-S3, Mon. Weather Rev., 136, 3018-3034. doi: http://dx.doi.org/10.1175/2008MWR2433.1, 2008.

Behringer, D.W., and Y. Xue.: Evaluation of the global ocean data assimilation system at NCEP: The Pacific Ocean. Eighth Symposium on Integrated Observing and Assimilation Systems for Atmosphere, Oceans, and Land Surface, AMS 84th Annual Meeting, Washington State Convention and Trade Center, Seattle, Washington, 11-15, 2004.

Branstator, G.: Circumglobal teleconnections, the jet stream waveguide, and the North Atlantic Oscillation, J. Clim., 15, 1893-1910, 2002.

Broecker, W.S.: Does the trigger for abrupt climate change reside in ocean or in the atmosphere? Science., 300, 1519-1522, 2003.

Curry, R., Dickson, B., and Yashayaev, I.: A change in the freshwater balance of the Atlantic Ocean over the past four decades, Nature., 426, 826-829, 2003.

Danabasoglu, Gokhan., Steve G. Yeager., Young-Oh Kwon., Joseph J. Tribbia., Adam S. Phillips., and James W. Hurrell.: Variability of the Atlantic Meridional Overturning Circulation in CCSM4, J. Climate., 25, 5153-5172. doi: http://dx.doi.org/10.1175/JCLI-D-11-00463.1, 2012 .

Delcroix, T., and M. McPhaden.: Interannual sea surface salinity and temperature changes in the western Pacific warm pool during 1992-2000, J. Geophys. Res., 107, 8002, doi: 101029/2001JC000862 , 2002.

Hoerling, M., Hurrell, J.W., and T. Xu.: Tropical origins for recent North Atlantic climate change, Science., 292, 90-92, DOI: 10.1126/science.1058582, 2001.

Huffman, G. J., Adler, R. F., Arkin, P., Chang, A., Ferraro, R., Gruber, A., Janowiak, J., McNab, A., Rudolf, B., and Schneider, U.: The global precipitation climatology project (GPCP) combined precipitation dataset, Bull. Am. Meteorol. Soc., 78, 5-20, doi: 10.1175/1520-0477(1997)078<0005: TGPCPG>2.0.CO; 2, 1997.

Huang, B., and Mehta, V. M.: Response of the Pacific and Atlantic oceans to interannual variations in net atmospheric freshwater, J. Geophys. Res., 110, C08008, doi:10.1029/2004JC002830, 2005

Jevrejeva, S., Moore, J. C., and Grinsted, A.: Oceanic and atmospheric transport of multiyear El NiñSouthern Oscillation (ENSO) signatures to the polar regions, Geophys. Res. Lett., 31, L24210, doi:10.1029/2004GL020871, 2004.

Kirtman, B.P., Cecilia Bitz., Frank Bryan., William Collins., John Dennis., Nathan Hearn., James L. Kinter., Richard, Loft., Clement, Rousset., Leo, Siqueira., Cristiana, Stan., Robert, Tomas., Mariana, Vertenstein.: Impact of ocean model resolution on CCSM climate simulations, Climate Dynamics 39, 1303-1328, 2012.

Laine, A., Nakamura, H., Nishii, K., and Miyasaka, T.: A diagnostic study of future evaporation changes projected in CMIP5 climate models, Clim Dyn., 42(9):2745-2761, 2014.

Selten, F.M., Branstator, G., Kliphuis, M., and Dijkstra, H.A.: Tropical origins for recent and future Northern Hemisphere climate change, Geophys. Res. Lett., 31, doi: 10.1029/2004GL020739, 2004.

Stouffer, R.J., Dan, Seidov., and Bernd, J. Haupt.: Climate Response to External Sources of Freshwater: North Atlantic versus the Southern Ocean, J. Climate., 20, 436-448. doi: http://dx.doi.org/10.1175 /JCLI4015.1, 2007. 
Nat. Hazards Earth Syst. Sci. Discuss., doi:10.5194/nhess-2016-83, 2016

Manuscript under review for journal Nat. Hazards Earth Syst. Sci.

Published: 18 March 2016

(c) Author(s) 2016. CC-BY 3.0 License.

Timmermann, A., An, S., Krebs,U., and Goosse, H.: ENSO suppression due to a weakening of the North Atlantic thermohaline circulation, J. Climate., 18, 3122-3139, 2005.

Williams, P. D., Guilyardi, E., Sutton, R. T., Gregory, J. M., and Madec, G.: On the climate response of the low-latitude Pacific Ocean to changes in the global freshwater cycle, Climate Dyn., 27, 593-611, 2006.

Wu, L, Li, C., Yang, C., and Xie, S.-P.: Global teleconnections in response to a shutdown of the Atlantic meridional overturning circulation, J. Climate., 21, 3002-3019, 2008.

Yeager, Stephen., and Danabasoglu, Gokhan.: Sensitivity of Atlantic Meridional Overturning Circulation Variability to Parameterized Nordic Sea Overflows in CCSM4, J. Climate., 25, 2077-2103. doi: http://dx.doi.org/10.1175/JCLI-D-11-00149.1, 2012.

Zhang, L., Wu, L., and Zhang, J.: Coupled ocean-atmosphere responses to recent freshwater flux changes over the Kuroshio-Oyashio Extension region, J. Climate., 24, 1507-1524, 2011a.

Zhang, L., Wu, L., and Zhang, J.: Simulated response to recent freshwater flux change over the Gulf Stream and its extension: Coupled ocean-atmosphere adjustment and Atlantic-Pacific teleconnection, J. Climate., 24, 3971-3988, 2011 b.

Zhang, R.H., and Busalacchi, A.J.: Freshwater flux (FWF)-induced oceanic feedback in a hybrid coupled model of the tropical Pacific, J. Climate., 22, 853-879, 2009.

Zheng, F., and Zhang, R.-H.: Effects of Interannual Salinity Variability and Freshwater Flux Forcing on the Development of the 2007/08 La Niña Event Diagnosed from Argo and Satellite Data, Dyn. Atmos. Ocn., 57, 45-57, 2012. 